\title{
PENANAMAN NILAI-NILAI PENDIDIKAN AKIDAH MELALUI MATA PELAJARAN SEJARAH KEBUDAYAAN ISLAM (SKI)
}

\author{
M. YUSUF AHMAD \\ Universitas Islam Riau \\ Jl. Kaharuddin Nasution, No. 113, Perhentian Marpoyan Pekanbaru 28284 \\ e-mail: m.yusuf_ahmad@fis.uir.ac.id \\ SYAHRAINI TAMBAK \\ Universitas Islam Riau \\ Jl. Kaharuddin Nasution, No. 113, Perhentian Marpoyan Pekanbaru 28284 \\ e-mail: syahraini_tambak@fis.uir.ac.id \\ RESTI RUSKARINI \\ Universitas Islam Riau \\ Jl. Kaharuddin Nasution, No. 113, Perhentian Marpoyan Pekanbaru 28284 \\ e-mail: m.yusuf_ahmad@fis.uir.ac.id
}

\begin{abstract}
Abstrak: Akidah merupakan ketentuan dasar mengenai keimanan seorang muslim dan landasan dari segala perilakunya. Mata pelajaran Sejarah Kebudayaan Islam merupakan perkembangan perjalanan hidup manusia muslim dari masa ke masa dalam usaha bersyari'ah dan berakhlak serta mengembangkan sistem kehidupan yang dilandasi akidah. Pada zaman sekarang ini banyak siswa yang belum menanamkan nilai-nilai pendidikan akidah dalam dirinya sehingga guru seharusnya terus berperan aktif dalam menanamkan nilai-nilai pendidikan akidah ini. Begitu juga gambaran yang ditemukan pada siswa di MTs An-Nur Desa Hangtuah Kecamatan Perhentian Raja Kabupaten Kampar. Setelah dilakukannya observasi, penulis menemukan adanya beberapa gejalagejala yang terjadi, diantaranya: guru kurang membiasakan penanaman nilai-nilai pendidikan akidah pada mata pelajaran Sejarah Kebudayaan Islam (SKI), guru kurang menanamkan sikap kepercayaan diri pada peserta didik dalam mata pelajaran Sejarah Kebudayaan Islam (SKI), guru kadang-kadang lupa mengajarkan nilai-nilai pendidikan akidah pada peserta didik dalam mata pelajaran Sejarah Kebudayaan Islam (SKI). Rumusan masalah: bagaimana penanaman nilai-nilai pendidikan akidah pada mata pelajaran SKI di MTs An-Nur Hangtuah. Tujuan penelitian untuk mengetahui penanaman nilai-nilai pendidikan akidah melalui mata pelajaran Sejarah Kebudayaan Islam (SKI) di MTs An-Nur Hangtuah. Berdasarkan pengolahan dan analisis data dapat disimpulkan bahwa guru menanamkan sikap percaya diri dan berupaya untuk mempertahankan harga diri, guru menanamkan untuk berlaku jujur dan adil dengan mencontoh dari kehidupan Rasulullah, guru menanamkan sikap sabar dan berpendirian teguh dengan meneladani para rasul yang mendapat gelar Ulul Azmi, guru menanamkan sikap ksatria, semangat dan berani pada diri siswa dengan meneladani perjuangan Rasulullah dan para pejuang Islam lainnya, guru menanamkan sikap patuh dan taat menjalankan perintah Allah dengan beriman kepada Allah menjalankan perintahNya seperti sholat, puasa, menuntut ilmu serta menggunakan waktu dengan sebaik-baiknya.
\end{abstract}

Kata Kunci: Penanaman, Nilai-Nilai, Pendidikan Akidah 


\section{PENDAHULUAN}

Menurut UU No. 20 th. 2003, pendidikan adalah usaha sadar dan terencana untuk mewujudkan suasana belajar dan proses pembelajaran agar peserta didik secara aktif mengembangkan potensi dirinya untuk memiliki kekuatan spiritual keagamaan, pengendalian diri, kepribadian, kecerdasan, akhlak mulia, serta keterampilan yang diperlukan dirinya, masyarakat, bangsa dan negara.

Secara umum, makna pendidikan sebagai usaha manusia untuk menumbuhkan dan mengembangkan potensi-potensi pembawaan baik jasmani dan rohani sesuai dengan nilai-nilai yang ada di dalam masyarakat dan kebudayaan. Usaha-usaha yang dilakukan untuk menanamkan nilai-nilai dan norma-norma tersebut serta mewariskannya kepada generasi berikutnya untuk dikembangkan dalam hidup dan kehidupan yang terjadi dalam suatu proses pendidikan.

Pendidikan bagi kehidupan umat manusia merupakan kebutuhan yang mutlak yang harus dipenuhi sepanjang hayat. Tanpa pendidikan sama sekali mustahil suatu kelompok manusia dapat hidup berkembang sejalan dengan aspirasi (cita-cita) untuk maju, sejahtera dan bahagia menurut konsep pandangan mereka.

Pendidikan sebagai salah satu sektor yang paling penting dalam pembangunan nasional, dijadikan andalan utama untuk berfungsi semaksimal mungkin dalam upaya meningkatkan kualitas hidup manusia Indonesia, dimana iman dan takwa kepada Tuhan Yang Maha Esa menjadi sumber motivasi (Ihsan, 2008:02-04).

Di dalam suatu budaya atau kultur sesuatu bangsa, sistem nilai merupakan landasan atau tujuan dari kegiatan seharihari yang menentukan dan mengarahkan bentuk, corak intensitas, kelenturan (flexible), perilaku seseorang atau sekelompok orang (Ahmadi \& Salimi, 2008:203).

Nilai-nilai luhur agama Islam yang diajarkan kepada peserta didik bukan hanya untuk dihafal menjadi ilmu pengetahuan atau kognitif, tapi adalah untuk dihayati (afektif) dan diamalkan dalam kehidupan sehari-hari. Islam adalah agama yang menuntut kepada pemeluknya untuk mengerjakannya sehingga menjadi umat yang beramal saleh.

Islam mengakui bahwa manusia adalah makhluk dualisme yang menyatu di dalam dirinya unsur jasmani dan rohani yang harus dijaga perkembangannya secara seimbang. Amal saleh merupakan aplikasi dari penghayatan terhadap nilai-nilai luhur agama (Ihsan, 2008:159)

Menurut Ahmad (1998: 10), antara amal perbuatan dan keyakinan (akidah) terdapat kaitan erat dan perbuatan yang timbul merupakan konsekuensi logis dari keyakinan yang ada dalam diri seorang mukmin terhadap Allah SWT.

Orang yang berakidah berarti orang yang beriman. Orang beriman itu adalah orang yang meyakini Allah dan Rasul-Nya kemudian tidak ragu-ragu untuk berjihad dengan harta dan diri di jalan Allah. Keyakinan pada Allah dan Rasul sebagai utusannya yang menyampaikan segala risalah Allah telah membentuk kesadaran diri, bahwa hidup manusia tidak akan lepas dari rencana dan ketetapan Allah (Syamsuddin, 2009:70).

Menurut ajaran Islam bila seseorang ragu akan keagungan Allah, namun lebih yakin pada kemampuan dirinya dengan pertolongan makhluk, maka jangan salahkan siapapun kalau dalam hidupnya ia akan menemukan banyak kekecewaan.

Barang siapa yang ingin hidupnya selalu dilindungi, dibela, dimudahkan urusannya oleh Allah, dikabulkan doadoanya, tetapi tidak pernah bersungguhsungguh meningkatkan akidah (keyakinannya) kepada Allah, maka 
keinginannya hanya akan menjadi sebuah angan-angan (Alim, 2006:131-132).

Akidah sebagai ketentuanketentuan dasar mengenai keimanan seorang muslim adalah merupakan landasan dari segala perilakunya, bahkan sebenarnya akidah merupakan pedoman bagi seseorang berperilaku di muka bumi. Oleh karena itu akidah tidak hanya berfungsi landasan secara pasif, karena akidah tidak hanya merupakan ukuran (standar) untuk mengukur perilaku seseorang itu sesuai atau tidak, akan tetapi akidah itupun merupakan titik tolak untuk seseorang berperilaku (Ahmadi dan Salimi, 2008:254).

Salah satu isi dari tujuan pendidikan Nasional adalah membentuk keimanan dan ketakwaan peserta didik. Dalam rangka mewujudkan tujuan tersebut terdapat mata pelajaran Pendidikan Agama Islam yang berupaya membentuk para peserta didik menjadi peserta didik yang beriman, bertakwa karena pengertian Pendidikan Agama islam menurut Direktorat Pembinaan Pendidikan Agama Islam Pada Sekolah Umum Negeri (Ditbinpaisun) adalah suatu usaha bimbingan dan asuhan terhadap anak didik agar nantinya setelah selesai dari pendidikan dapat memahami apa yang terkandung di dalam Islam secara keseluruhan, menghayati makna dan maksud serta tujuannya dan pada akhirnyadapat mengamalkannya serta menjadikan ajaran-ajaran agama Islam yang telah dianutnya itu sebagai pandangan hidupnya sehingga dapat mendatangkan keselamatan dunia dan akhirat kelak.

Berkenaan dengan lembaga yang menyelenggarakan pendidikan keagamaan ini, tampaknya, minimal ada tiga bentuk yaitu: (a) Pesantren; (b) Madrasah-madrasah keagamaan (diniyah); dan (c) Madrasah-madrasah yang termasuk pendidikan umum berciri khas agama, yaitu Madrasah Ibtidaiyah,
Tsanawiyah, dan Aliyah (Hasbullah, 2008:183).

Di Madrasah Tsanawiyah An-Nur, terdapat sub-sub mata pelajaran PAI yang meliputi: mata pelajaran Al-Qur'an Hadist, Fiqih, Akidah Akhlak dan Sejarah Kebudayaan Islam. Hubungan antara satu pelajaran dengan pelajaran lain saling berkaitan dan diibaratkan sebagai satu mata rantai. Mata pelajaran Sejarah Kebudayaan Islam merupakan perkembangan perjalanan hidup manusia muslim dari masa ke masa dalam usaha bersyari'ah dan berakhlak serta mengembangkan sistem kehidupan yang dilandasi akidah.

Dalam sejarahnya, perjuangan Rasulullah SAW., di mana hampir selama periode Mekkah Rasulullah SAW., mengerahkan usahanya untuk membina tauhid umat Islam. Rasul selalu menekankan tauhid dalam setiap ajarannya, sebelum seseorang diberi pelajaran lain. Maka tauhid ditanamkan terlebih dahulu kepada mereka (Alim,2006:134).

Dalam perkembangan awal sejarah Islam, kehidupan beragama dikalangan para sahabat Rasulullah SAW. terlihat sangat sederhana dan tidak rumit. Apa yang diajarkan oleh Nabi kepada mereka, langsung mereka laksanakan, dan apa yang beliau perintahkan untuk ditinggalkan, tanpa banyak tanya, mereka tinggalkan pula. Setiap datang ayat yang mengandung perintah atau larangan, selalu mereka laksanakan, dan mereka belum akan beranjak dari satu ayat ke ayat yang lain sepanjang ayat yang pertama belum bisa mereka amalkan dengan baik. Sementara itu, dalam masalah peribadatan, mereka selalu mengamati apa yang dilakukan oleh Nabi, serta berusaha keras untuk selamanya beribadah sesuai dengan apa yang beliau laksanakan.

Jika dikaitkan dengan pendidikan, pendidikan berusaha memberikan bimbingan kepada peserta didik untuk 
menjadi peserta didik yang beriman dan bertakwa. Dimulai dari membina akidah sedari kecil oleh keluarganya kemudian dikembangkan dalam jalur pendidikan sekolah salah satunya melalui mata pelajaran Sejarah Kebudayaan Islam diantaranya membahas tentang perjuangan Rasulullah pada periode Mekkah.

Dalam masa pembinaan pendidikan agama Islam di Mekah Nabi Muhammad mengajarkan Al-Qur'an karena Al-Qur'an merupakan inti sari dan sumber pokok ajaran Islam serta Nabi Muhammad SAW mengajarkan tauhid kepada umatnya, memberikan pendidikan keagamaan dan akhlak serta memberikan contoh dalam melaksanakan perintah dan larangan-nya yang didapat dari wahyu Allah SWT.

Di dalam pengajaran, pendidik diharapkan dapat meneladani perjuangan Rasulullah dalam menyiarkan agama Islam begitu pula tugas pendidik dalam mendidik peserta didiknya dan memberikan contoh yang baik, pendidik sangat berperan dalam mendidik peserta didiknya agar menjadi pribadi muslim yang baik demi berkembangnya pendidikan Islam yang akan datang. Peranan seorang pendidik sangat berpengaruh terhadap kepribadian peserta didiknya. Oleh karena itu, apabila seorang pendidik kurang menanamkan nilai-nilai pendidikan akidah pada peserta didiknya maka lambat laun peserta didik akan semakin jauh dari ajaran akidah yang diajarkan dalam pendidikan agama Islam. Akibatnya nilai-nilai pendidikan akidah akan semakin hilang dari kepribadian peserta didiknya.

Dalam pembelajaran sejarah Islam yang dimaksudkan adalah untuk mengembangkan dan mengambil ibrah pelajaran Sejarah Kebudayaan Islam, sehingga peserta didik mampu menginternalisasi dan tergerak untuk meneladani dan mewujudkan dalam amal perbuatan, serta dalam rangka membangun sikap terbuka dan toleran atau semangat Ukhuwah Islamiyah.

Dari yang dikemukakan diatas bahwa pentingnya nilai-nilai pendidikan akidah pada setiap pembelajaran khususnya mata pelajaran Sejarah Kebudayaan Islam (SKI), tidak hanya untuk dihafal tetapi untuk ditanamkan dan diamalkan dalam kehidupan sehariharinya.

Namun berbeda dengan yang terjadi di Madrasah Tsanawiyah (MTs) An-Nur,di madrasah tersebut ditemukan beberapa gejala seperti yang terjadi seperti berikut ini: (1) Guru kurang membiasakan penanaman nilai-nilai pendidikan akidah pada peserta didik dalam mata pelajaran Sejarah Kebudayaan Islam (SKI); (2) Guru kurang menanamkan sikap kepercayaan diri pada peserta didik dalam mata pelajaran Sejarah Kebudayaan Islam (SKI); dan (3) Guru kadang-kadang lupa mengajarkan nilai-nilai pendidikan akidah pada peserta didik dalam mata pelajaran Sejarah Kebudayaan Islam (SKI)

Dari uraian di atas penulis tertarik untuk membuat penelitian dengan judul: Penanaman Nilai-Nilai Pendidikan Akidah Melalui Mata Pelajaran Sejarah Kebudayaan Islam(SKI) di MTs An-Nur Desa Hangtuah Kecamatan Perhentian Raja Kabupaten Kampar.

Berdasarkan latar belakang permasalahan diatas, maka penulis membatasi pembahasan ini pada masalah penanaman nilai-nilai pendidikan akidah melalui mata pelajaran Sejarah Kebudayaan Islam (SKI) di MTs An-Nur Desa Hangtuah Kecamatan Perhentian Raja Kabupaten Kampar.

Berdasarkan pembatasan masalah di atas maka rumusan masalah dalam penelitian ini adalah bagaimana penanaman nilai-nilai pendidikan akidah melalui mata pelajaran Sejarah Kebudayaan Islam (SKI) di MTs An-Nur Desa Hangtuah Kecamatan Perhentian Raja Kabupaten Kampar? 
Berdasarkan rumusan masalah yang dikemukakan, penelitian ini bertujuan untuk mengetahui penana-man nilai-nilai pendidikan akidah melalui mata pelajaran Sejarah Kebudayaan Islam (SKI) di MTS An-Nur Desa Hangtuah Kecamatan Perhentian Raja Kabupaten Kampar.

\section{METODE}

Menurut Bogdan dan Taylor, penelitian kualitatif adalah prosedur penelitian yang menghasilkan data deskriptif berupa kata-kata tertulis atau lisan dari orang-orang dan perilaku yang dapat diamati (Moleong, 2013: 04).

Penelitian kualitatif adalah penelitian tentang riset yang bersifat deskriptif dan cenderung menggunakan analisis. Proses dan makna (perspektif subjek) lebih ditonjolkan dalam penelitian kualitatif. Landasan teori dimanfaatkan sebagai pemandu agar fokus penelitian sesuai dengan fakta di lapangan. Selain itu landasan teori juga bermanfaat untuk memberikan gambaran umum tentang latar penelitian dan sebagai bahan pembahasan hasil penelitian. Terdapat perbedaan mendasar antara peran landasan teori dalam penelitian kuantitatif dengan penelitian kualitatif. Dalam penelitian kuantitatif, penelitian berangkat dari teori menuju data, dan berakhir pada penerimaan atau penolakan terhadap teori yang digunakan; sedangkan dalam penelitian kualitatif peneliti bertolak dari data, memanfaatkan teori yang ada sebagai bahan penjelas, dan berakhir dengan suatu "teori".

Kriyantono menyatakan bahwa "riset kualitatif bertujuan untuk menjelaskan fenomena dengan sedalamdalamnya melalui pengumpulan data sedalam-dalamnya.". Penelitian kuali-tatif menekankan pada kedalaman data yang didapatkan oleh peneliti. Semakin dalam dan detail data yang didapatkan, maka semakin baik kualitas dari penelitian kualitatif ini. Berbeda dengan kuantitatif, objek dalam penelitian kualitatif umumnya berjumlah terbatas. Dalam penelitian ini, peneliti ikut serta dalam peristiwa/kondisi yang sedang diteliti. Untuk itu hasil dari penelitian ini memerlukan kedalaman analisis dari peneliti. Selain itu, hasil penelitian ini bersifat subjektif sehingga tidak dapat digeneralisasikan. Secara umum, penelitian kualitatif dilakukan dengan metode wawancara dan observasi. Melalui metode ini, peneliti akan menganalisis data yang didapatkan dari lapangan dengan detail. Peneliti tidak dapat meriset kondisi sosial yang diobservasi, karena seluruh realitas yang terjadi merupakan kesatuan yang terjadi secara alamiah. Hasil dari penelitian kualitatif juga dapat memunculkan teori atau konsep baru apabila hasil penelitiannya berten-tangan dengan teori dan konsep yang sebelumnya dijadikan sebagai kajian dalam penelitian.

Penelitian kualitatif jauh lebih subjektif daripada penelitian atau survei kuantitatif dan menggunakan metode sangat berbeda dari mengumpulkan informasi, terutama individu, dalam menggunakan wawancara secara mendalam dan group fokus. Sifat dari jenis penelitian ini adalah penelitian dan penjelajahan terbuka berakhir dilakukan dalam jumlah relatif kelompok kecil yang diwawancarai secara mendalam.

Peserta diminta untuk menjawab pertanyaan umum, dan pewawancara atau moderator group periset menjelajah dengan tanggapan mereka untuk mengidentifikasi dan menentukan persepsi, pendapat dan perasaan tentang gagasan atau topik yang dibahas dan untuk menentukan derajat kesepakatan yang ada dalam grup. Kualitas hasil temuan dari penelitian kualitatif secara langsung tergantung pada kemampuan, pengalaman dan kepekaan dari pewawancara.

Penelitian Dilaksanakan Di Madrasah Tsanawiyah (MTs) An-Nur 
Desa Hangtuah Kecamatan Perhentian Raja Kabupaten Kampar, Jalan Poros Desa Hangtuah. Adapun waktu penelitian ini penulis lakukan selama 4 bulan yakni Bulan Desember 2016 sampai dengan bulan Maret 2017.

Subjek penelitian ini adalah Guru Mata pelajaran Sejarah Kebudayaan Islam di Madrasah Tsanawiyah An-Nur Desa Hangtuah Kecamatan Perhentian Raja Kabupaten Kampar. Objek penelitian ini adalah penanaman nilai-nilai pendidikan akidah melalui mata pelajaran Sejarah Kebudayaan Islam (SKI) di MTs An-Nur Desa Hangtuah Kecamatan Perhentian Raja Kabupaten Kampar.

Populasi dari penelitian ini adalah 1 orang guru Sejarah Kebudayaan Islam (SKI) di MTs An-Nur Desa Hangtuah Kecamatan Perhentian Raja Kabupaten Kampar.

Dalam penelitian ini peneliti menggunakan teknik pengumpulan data yaitu wawancara. Wawancara adalah percakapan dengan maksud tertentu. Percakapan itu dilakukan oleh dua pihak, yaitu pewawancara (interviewer) yang mengajukan pertanyaan dan terwawancara (interviewee) yang memberikan jawaban atas pertanyaan itu (Moleong, 2013:186). Selain wawancara, penelitian ini juga menggunakan teknik dokumentasi. Dokumentasi merupakan catatan peristiwa yang sudah berlalu. Dokumen yang digunakan peneliti disini berupa foto, gambar,rekaman dan datadata mengenai profil sekolah MTs An-Nur Hangtuah (Sugiyono, 2012:326).

Proses analisis merupakan usaha untuk menemukan jawaban atas pertanyaan perihal informasi, rumusanrumusan dan hal-hal yang kita peroleh didalam penelitian (Dairi, 2014:83).

Aktifitas dalam analisis data yaitu: (1) Reduksi Data (Data Reduction). Reduksi data merupakan proses berfikir sensitif yang memerlukan kecerdasan dan keluasan serta kedalaman wawasan yang tinggi. Dalam mereduksi data, setiap peneliti akan dipandu oleh tujuan yang akan dicapai. Tujuan utama dari penelitian kualitatif adalah pada temuan. Oleh karna itu, kalau peneliti dalam melakukan penelitian, menemukan segala sesuatu yang dipandang asing, tidak dikenal, belum memiliki pola, justru itulah yang harus dijadikan perhatian peneliti dalam melakukan reduksi data; (2) Penyajian Data (Data Display). Setelah data direduksi, maka langkah selanjutnya adalah mendisplaykan data. Dengan mendisplaykan data, maka akan memudahkan untuk memahami apa yang terjadi, merencanakan kerja selanjutnya berdasarkan apa yang telah dipahami tersebut; (3) Conclusion Drawing/Verification. Langkah ketiga dalam analisis data kualitatif adalah penarikan kesimpulan dan verifikasi. Kesimpulan awal yang dikemukakan masih bersifat sementara, dan akan berubah bila tidak ditemukan bukti-bukti yang kuat yang mendukung pada tahap pengumpulan data berikutnya. Tetapi apabila kesimpulan yang dikemukakan pada tahap awal, didukung oleh buktibukti yang valid dan konsisten saat peneliti kembali kelapangan mengumpulkan data, maka kesimpulan yang dikemukakan merupakan kesimpulan yang kredibel (Sugiyono, 2012:336-343).

\section{HASIL}

\section{Gambaran Umum dan Sejarah Berdirinya Madrasah Tsanawiyah (Mts) An-Nur}

Desa Hangtuah merupakan salah satu desa ekstransmigrasi yang dibuka sekitar tahun 1985 dan mulai dihuni sejak tahun 1989. Sebelum berubah nama menjadi desa, lokasi ini bernama UPT (Unit Pemukiman Transmigrasi) yang terdiri dari dua SP (Satuan Pemukiman) yaitu SP 1 dan SP II yang dipimpin oleh satu orang KUPT (Ketua Unit Pemukiman Transmigrasi). 
Setelah pemukiman ini diserahkan kepada Pemerintah Daerah Tingkat II Kampar, UPT yang terdiri dari dua SP dijadikan satu desa, yaitu Desa Hangtuah. Sebagai desa ekstrans-migrasi, Desa Hangtuah memiliki penduduk yang sangat majemuk, baik dari segi ras (suku), agama, maupun latar belakang sosial budaya dan pendidikan.

Pada awal kedatangan penduduk transmigrasi ini semua bermata pencaharian sebagai petani, yaitu menggarap ladang yang disediakan oleh pemerintah di sekitar rumah mereka dengan luas $100 \mathrm{M}$ x $50 \mathrm{M}$. Akan tetapi seiring dengan beralihnya sistem pemerintahan dari sistem UPT kepada sistem Desa, maka banyak warga Desa Hangtuah yang masih berdagang dengan cara membuka atau mendirikan warung

Secara geografis, Desa Hangtuah sebagai desa eks transmigrasi mempunyai jarak 30 kilometer dari ibu kota Provinsi Riau (Pekanbaru). Desa ini berbatasan dengan Desa Sialang Kubang di sebelah barat, disebelah timur dengan Desa Pantai Raja, di sebelah selatan dengan Desa Simpang Dua, dan sebelah utara berbatasan dengan areal perkebunan PTPN V Sungai Pagar.

Sebagai desa ekstransmigrasi, kebutuhan masyarakat belum sepenuhnya terpenuhi. Sarana pendidikan yang merupakan salah satu kebutuhan vital bagi masyarakat pendatang ini juga belum tersedia. Berdasarkan kepada permasalahan tersebut maka berkat kerjasama semua elemen masyarakat dapat mendirikan sebuah Lembaga Pendidikan Islam (LPI), dengan nama An-Nur yang terdiri dari MDA (Madrasah Diniyah Awaliyah) dan MTs (Madrasah Tsanawiyah).

Madrasah Tsanawiyah (MTs) AnNur berdiri pada tanggal 15 Juli 1991 dan memiliki luas tanah $10.000 \mathrm{~m}^{2}$. Adapun tokoh-tokoh pendiri Madrasah Tsanawiyah (MTs) An-Nur : Bapak M. Yunus (alm), Bapak Hamzah Alimuddin (alm), Bapak Badrus Sholih, Bapak Idih Supriadi (alm), Bapak M. Sumari, Bapak Syamri Alam (kepala desa saat itu), dan Bapak Karsono (alm).

Adapun visi dari Madrasah Tsanawiyah (MTs) An- Nur adalah: "Mempersiapkan generasi Islam yang sehat, berkualitas, beraqidah, berakhlak sesuai dengan Al-Qur'an dan sunah Rasul." Sedangkan misi dari Madrasah Tsanawiyah (MTs) An- Nur adalah: "(1) Memberikan pelayanan pendidikan Islam untuk menghadapi globalisasi yang semakin bebas; (2) Memberikan pendidikan berupa skill/keahlian serta sikap yang dapat diterapkan sekaligus sebgai bekal ke jenjang yang lebih tinggi; dan (3) Menyatukan kemampuan sikap dan watak Islami dengan ilmu pengetahuan sehingga peserta didik dapat tumbuh dan berkembang potensinya.

Pada saat penelitian dilaksanakan, Madrasah Tsanawiyah An-Nur mempunyai 19 orang guru baik dari PNS, kontrak tenaga honorer. Adapun guru Sejarah Kebudayaan Islam (SKI) yang diwawancarai yaitu bapak H. H. Djarjis Djamaluddin, BA. Beliau telah menjadi guru di MTs An-Nur sejak tahun 2000sampai sekarang.

Keadaan siswa Madrasah

Tsanawiyah An-Nur dari tahun ketahun selalu mengalami perubahan jumlah, baik berkurang maupun bertambah. Namun pada saat penelitian dilaksanakan jumlah siswa Madrasah Tsanawiyah An-Nur adalah berjumlah 78 siswa yang terbagi menjadi 4 (empat) lokal, 2 kelas VII, 1 kelas VIII dan satu kelas IX. Siswa pada kelas VIIA berjumlah 19 siswa, yang terdiri dari 12 laki-laki dan 7 perempuan. Siswa pada kelas VIIB berjumlah 19 siswa, yang terdiri dari 11 laki-laki dan 8 perempuan. Siswa pada kelas VIII berjumlah 14 siswa, yang terdiri dari 9 laki-laki dan 5 perempuan. Sedangkan siswa pada kelas IX berjumlah 26 siswa, 
yang terdiri dari 15 laki-laki dan 11 perempuan.

\section{Penanaman Nilai-nilai Pendidikan Akidah Melalui Mata Pelajaran Sejarah kebudayaan Islam (SKI)}

Sehubungan dengan tujuan penelitian ini, yaitu untuk mengetahui bagaimana penanaman nilai-nilai pendidikan akidah pada mata pelajaran Sejarah Kebudayaan Islam (SKI) Di Mts An-Nur Hangtuah, maka penulis melakukan penelitian dengan teknik wawancara. Untuk memperoleh data yang diperlukan penulis melakukan wawancara dengan satu orang guru Sejarah kebudayaan Islam (SKI) di MTs An-Nur Hangtuah. Berikut hasil dari wawancara yang penulis lakukan dengan guru Sejarah kebudayaan Islam (SKI) di MTs An-Nur Hangtuah:

\section{Wawancara Pertama}

Wawancara pertama dengan guru Sejarah Kebudayaan Islam (SKI) pada hari Selasa, 13 Desember 2016 :

T: Bagaimana penanaman yang dilakukan Bapak/Ibu dalam menanamkan sikap percaya diri pada diri siswa?

J: $\quad$ Setiap makhluk yang tergolong manusia harus percaya diri dalam segala hal dan tidak boleh putus asa atas nikmat yang diberikan Tuhan. Rasa percaya diri itu diambil dari kata amanah. Penerapannya kepada siswa sesuai dengan sifat amanah yang diterapkan Rasulullah SAW. yaitu harus memiliki sifat percaya kepada orang lain supaya lengket terhadap kita sendiri.

T: Bagaimana penanaman yang dilakukan Bapak/Ibu dalam menanamkan sikap harga diri pada diri siswa?

J: Harga diri itu sangat tinggi nilainya, bila kita kehilangan harga diri berarti tidak berharga di masyarakat, tidak hanya di lingkungan masyarakat tetapi dilingkungan keluarga dan sekolah.

T: Bagaimana penanaman yang dilakukan Bapak/Ibu dalam membentuk sikap jujur pada diri siswa?

J: Kita harus bersikap jujur dalam kehidupan sehari-sehari, karena sikap jujur itu dianjurkan dalam agama dalam hidup bermasyarakat dan kejujuran itu merupakan suatu sifat Rasulullah SAW. yang harus kita contoh dan kita teladani dalam kehidupan sehari-hari.

T: Bagaimana penanaman yang dilakukan Bapak/Ibu dalam membentuk sikap adil pada diri siswa?

J: Bahwa kita sebagai siswa harus bersikap adil terhadap diri sendiri maupun di lingkungan masyarakat, kita harus bersikap adil dalam perkataan, perbuatan dan sikap, seperti firman Allah yang artinya: "bila kamu menghukum diantara manusia maka hukumlah dengan seadil-adilnya".

T: Bagaimana penanaman yang dilakukan Bapak/Ibu dalam menghilangkan sifat murung dalam menghadapi setiap persoalan pada diri siswa?

J: Bahwa kita sebagai seorang siswa harus bersifat ceria dan tidak boleh bersifat murung dalam menghadapi semua problema hidup, terutama di sekolah maupun di rumah. Sulitnya menghadapi pelajaran sehingga timbulnya sifat murung dan patah semangat, masalah di rumah dibawa sampai ke sekolah.

T: Bagaimana penanaman yang dilakukan Bapak/Ibu dalam menghilangkan sifat putus asa dalam menghadapi setiap persoalan pada diri siswa?

J: Bahwa kita sebagai manusia tentu dituntut oleh ajaran agama kita bahwasannya tidak boleh putus asa 
dalam kehidupan ini dan kita harus berusaha semaksimal mungkin namun keputusannya tetap berada ditangan Allah SWT.

T: Bagaimana penanaman yang dilakukan Bapak/Ibu dalam menanamkan sifat kesatria pada diri siswa?

J: Bahwa kita sebagai siswa harus mencontoh dan meneladani para pejuang baik pejuang tokoh-tokoh Islam maupun tokoh-tokoh Nasional Negara Indonesia. Sebagai contoh pejuang Islam yang harus kita teladani yaitu jiwa dari Salauddin AlAyubi yang membela agama dan negara. Dia adalah seorang Raja dan Panglima perang. Di Indonesia seperti Syarif Hidayatullah yang berjuang mengusir Belanda di Batavia.

T: Bagaimana penanamanyang dilaku-kan Bapak/Ibu dalam menanamkan sifat semangat pada diri siswa?

J: Bahwa kita sebagai siswa harus mempunyai semangat yang tinggi dalam kehidupan ini, yang pertama kita sebagai siswa harus mempunyai semangat yang tinggi dalam menuntut ilmu untuk mencapai hasil yang maksimal. Ada semangat tinggi belajar, berarti tidak ada rasa untuk menyontek dengan kawan lainnya.

T: Bagaimana penanamanyang dilakukan Bapak/Ibu dalam menanamkan sifat berani pada diri siswa?

J: Bahwa kita sebagai siswa harus mempunyai sifat berani dalam menegakkan kebenaran, berani dalam menghadapi persoalan untuk mencapai kebenaran. Penerapannya dalam pembelajaran yakni berani mengeluarkan pendapat meskipun berbeda dengan teman lainnya yang penting ada dasar dan rujukannya .

T: Bagaimana penanamanyang dilakukan Bapak/Ibu dalam menanamkan sifat tidak gentar menghadapi resiko pada diri siswa?

J: Bahwa kita sebagai siswa tidak boleh takut dan gentar menghadapi resiko.
Mencontoh perjuangan Rasulullah SAW. ketika berperang tidak gentar menghadapi resiko meskipun musuh yang banyak dalam perang Badar, tetapi demi perjuangan Rasulullah tidak gentar menghadapi semua itu.

T: Bagaimana penanamanyang dilakukan Bapak/Ibu dalam menanamkan sifat tidak takut mati pada diri siswa?

J: Bahwa kita sebagai manusia sebagai makhluk yang bernyawa tidak boleh takut untuk menghadapi kematian karena setiap yang bernyawa pasti akan mengalami sakit atau merasakan mati. Kematian itu pasti akan menemui kita kapan saja dan dimana kita berada. Dalam firman Allah SWT:

$$
\text { كُلْ تَفسِ ذَائقِةُ المَوْتِ }
$$

Artinya : "Setiap diri pasti merasai sakit dan mati".

Berdasarkan ayat tersebut kita tidak boleh takut dan lari dari kematian itu sendiri, karena kematian itu pasti akan menjumpai kita.

T: Bagaimana penanaman yang dilakukan Bapak/Ibu dalam membentuk sikap berpendirian teguh pada diri siswa?

J: Kita sebagai siswa harus mempu-nyai pendirian yang teguh dan tidak boleh bersifat seperti orang-orang munafik dan hanya ikut-ikutan saja. Dalam menghadapi tugas yang dipercaya belum tentu betul karena tidak mempunyai keteguhan diri.

T: Bagaimana penanaman yang dilakukan Bapak/Ibu dalam membentuk sikap sabar pada diri siswa?

J: Bahwa kita sebagai siswa harus mempunyai sifat sabar dalam segala hal kehidupan terutama dalam belajar karena sifat sabar itu akan membawa kita kepada keberhasilan. Kebanyakan orang yang gagal disebabkan tidak memiliki sifat sabar. Allah akan membantu orang-orang yang memiliki sifat sabar. Dalam firman Allah SWT: 


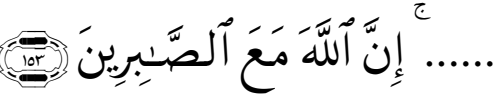

Artinya: ".....Allah akan selalu bersama orang-orang yang sabar." (Q.S. Al-Baqarah: 153).

Untuk menerapkan sikap sabar pada siswa dengan mencontoh rasul-rasul yang ulul azmi yang sabar dalam menghadapi hidup dan kehidupan. Dengan kesabaran itulah maka ditunjuk sebagai rasul pilihan.

T: Bagaimana penanamanyang dilaku-kan Bapak/Ibu dalam membentuk sikap optimisme pada diri siswa?

J: Sikap optimisme dalam kehidupan harus mencontoh Rasulullah, dia sangat bijak dalam mengambil keputusan. Optimis lawannya pesimis, optimis dalam pembelajaran seperti optimis dalam mengerjakan soal ujian.

T: Bagaimana penanaman yang dilakukan Bapak/Ibu dalam menciptakan sikap hidup damai pada diri siswa?

J: Bahwa kita sebagai siswa harus menciptakan hidup damai baik di lingkungan sekolah, di lingkungan rumah tanggadan di lingkungan masyarakat. Seperti yang kecil disayangi, sama besar dihargai dan yang lebih tua dihormati.

T: Bagaimana penanaman yang dilakukan Bapak/Ibu dalam membentuk sikap ridha pada diri siswa?

J: Bahwa kita sebagai siswa harus ridha terhadap pemberian dan anugerah yang diberikan Tuhan kepada kita dalam hal segala-galanya. Kemudian ridha dalam menghadapi permasalahan hidup yang dihadapi yang semuanya itu merupakan kehendak dari Allah SWT.

T: Bagaimana penanamanyang dilakukan Bapak/Ibu dalam membentuk sikap patuh dan taat menjalankan perintah Allah pada diri siswa?

J: Bahwa kita sebagai siswa terutama siswa MTs adalah siswa yang mengikuti sekolah agama, kita harus taat dan patuh menjalankan ajaran agama yang kita anut yaitu agama Islam seperti menjalankan perintah shalat lima waktu satu hari satu malam, puasa dan lain-lain.

T: Bagaimana penanaman yang dilakukan Bapak/Ibu dalam membentuk sikap disiplin menjalankan perintah Allah pada diri siswa?

J: Bahwa kita sebagai seorang siswa harus mempunyai sikap disiplin terhadap diri sendiri dan tidak boleh mengulur-ngulur waktu dan tidak boleh menunda-nunda waktu. Kita kerjakan hari ini, kerjakanlah karena hari besok sudah ada pekerjaan yang menunggu kita. Waktu seperti pedang kalau tidak bisa menggunakan maka akan hancur. Kalau bagi orang inggris time is money, bagi Indonesia waktu itu berharga. Pergunakanlah waktu muda itu untuk menuntut ilmu.

\section{Wawancara Kedua}

Wawancara kedua dengan guru Sejarah Kebudayaan Islam (SKI) pada hari Selasa, 27 Desember 2016:

T: Bagaimana penanaman yang dilakukan Bapak/Ibu dalam menanamkan sikap percaya diri pada diri siswa?

J: $\quad$ Setiap siswa dalam menghadapi belajar bidang studi Sejarah Kebudayaan Islam harus diikuti supaya mendapatkan hasil yang maksimal. Setiap pekerjaan yang diawali dengan baik belum tentu hasilnya baik apalagi kalau dikerjakan tidak serius. Jadi untuk percaya diri itu setiap belajar diikuti dengan baik supaya kita percaya diri dalam menghadapi ujian.

T: Bagaimana penanaman yang dilakukan Bapak/Ibu dalam menanamkan sikap tahu harga diri pada diri siswa?

J: Setiap siswa harus mengerti tentang harga diri, kita siswa MTs berbeda dengan siswa yang belajar dengan 
sekolah umum. Setiap tingkah laku, perbuatan kita sehari-hari, orangorang akan menyorot dari kacamata agama. Untuk itu kita harus menjaga harga diri baik di sekolah, di dalam keluarga dan di lingkungan masyarakat.

T: Bagaimana penanaman yang dilakukan Bapak/Ibu dalam membentuk sikap jujur pada diri siswa?

J: Setiap siswa harus bersikap jujur terhadap diri sendiri, keluarga dan juga di lingkungan sekitarnya, karena sikap jujur itu akan mengangkat harkat dan martabat diri dari setiap kita. Setiap siswa harus jujur dalam belajar dalam menghadapi ujian, dalam perbuatan dan tingkah laku, sebagai contoh: ketika ujian siswa harus bersikap jujur pada diri sendiri karena jujur itu dianjurkan dalam agama Islam dan mengarah pada sifat Rasulullah.

T: Bagaimana penanaman yang dilakukan Bapak/Ibu dalam membentuk sikap adil pada diri siswa?

J: $\quad$ Setiap siswa harus adil bersikap adil pada diri sendiri, teman dan keluarga. Bersikap adil dalam perkataan, perbuatan dan ketetapan, harus adil dari ketiganya itu. Contoh menengok situasi dan kondisinya, seperti seorang bapak yang memiliki tiga anak, yang satu di SD, satu lagi di SMP dan yang lainnya kuliah sudah jelas beda kebutuhan yang sesuai dengan kebutuhan mereka. Sikap adil juga berpedoman pada Al-Qur'an yang artinya: "apabila kamu menghukum di antara manusia maka hukumlah dengan seadil-adilnya".

T: Bagaimana penanaman yang dilakukan Bapak/Ibu dalam menghilangkan sifat murung dalam menghadapi setiap persoalan pada diri siswa?
J: Setiap siswa harus bersifat cerah dan ceria dalam menghadapi setiap persoalan sehari-hari terutama dalam belajar dan tidak boleh bersifat murung karena sifat murung sendiri tidak sesuai dalam ajaran Islam. Dalam belajar harus menghadapi pelajaran bersifat cerah supaya hasil dari pelajaran itu mencapai hal yang maksimal.

T: Bagaimana penanaman yang dilakukan Bapak/Ibu dalam menghilangkan sifat putus asa dalam menghadapi setiap persoalan pada diri siswa?

J: Setiap siswa tidak boleh berputus asa dalam menghadapi setiap persoalan yang dihadapi dalam kehidupan sehari-hari terutama dalam menghadapi pelajaran SKI, kita tidak boleh berputus asa, kalau orang lain bisa kita harus bisa juga. Pelajaran SKI itu banyak hafalannya, jadi harus berusaha.

T: Bagaimana penanaman yang dilakukan Bapak/Ibu dalam menanamkan sifat kesatria pada diri siswa?

J: $\quad$ Setiap siswa harus menanamkan dalam dirinya sendiri sifat kesatriaan karena siswa adalah sebagai pelopor pembangunan untuk masa yang akan datang. Sebagai contoh Salahuddin Al-Ayubi mendirikan sekolah sebanyak 9 di Mesir dan 11 di Syiria.

T: Bagaimana penanaman yang dilakukan Bapak/Ibu dalam menanamkan sifat semangat pada diri siswa?

J: Setiap siswa harus memiliki semangat belajar yang tinggi, semangat yang tinggi dalam menuntut ilmu. Tanpa memiliki semangat yang tinggi dalam menghadapi bidang studi SKI tidak akan dicapai hasil yang maksimal karena semangat belajar itu merupakan motivator 
yang sangat menentukan dari hasil pelajaran yang kita capai.

T: Bagaimana penanaman yang dilakukan Bapak/Ibu dalam menanamkan sifat berani pada diri siswa?

J: Setiap siswa harus mempunyai sifat yang berani, berani dalam mengeluarkan pendapat dalam belajar karena sifat berani merupakan dinamisator dalam mencapai suatu kebenaran, tanpa ada sifat keberanian dalam mengeluarkan pendapat terutama dalam pelajaran SKI, seorang siswa tidak akan mencapai hasil yang maksimal karena pelajaran SKI sangat luas ruang lingkupnya yaitu peradaban, sejarah umat Islam pada masa lampau atau sekitar 14 abad yang lalu sampai sekarang.

T: Bagaimana penanaman yang dilakukan Bapak/Ibu dalam menanamkan sifat tidak gentar menghadapi resiko pada diri siswa?

J: $\quad$ Seorang siswa tidak boleh bersifat gentar menghadapi resiko untuk mencapai hasil yang maksimal dari suatu persoalan terutama dalam bidang studi SKI karena suatu perbuatan sudah jelas ada resikonya terhadap siswa. Penerapanya seperti Rasulullah menyebarkan Islam ke Ta'if tetapi tidak mendapat sambutan baik malah dilempari dengan batu oleh masyarakat tapi Rasulullah tidak gentar menghadapi resiko pada saat itu karena Rasulullah menerapkan suatu kebenaran untuk manusia. Kita sebagai siswa harus mencontoh/meneladani hal yang dilakukan oleh Rasulullah.

T: Bagaimana penanaman yang dilakukan Bapak/Ibu dalam menanamkan sifat tidak takut mati pada diri siswa?

J: Kita sebagai seorang siswa tidak boleh takut menghadapi kematian karena kematian itu akan menemui kita di mana saja kita berada. Sesuai dengan ajaran Islam yang terdapat pada Al-Qur'an :"setiap diri yang bernyawa akan menemui kematian. Kita sebagai seorang siswa tidak boleh takut/lari dari kematian dan kita harus siap untuk menghadapi kematian itu sendiri karena kita tidak mengetahui di mana kita mati dan kapan waktunya kita mati. Oleh sebab itu kita harus siap menghadapi kematian itu sendiri.

T: Bagaimana penanaman yang dilakukan Bapak/Ibu dalam membentuk sikap berpendirian teguh pada diri siswa?

J: $\quad$ Setiap siswa mempunyai sikap berpendirian teguh atau istiqamah. Kita harus istiqamah dalam menghadapi bidang studi di sekolah khususnya SKI, kita harus istiqamah dalam belajar dan mengerjakan tugas, percaya pada diri sendiri sesuai materi yang sudah dipelajari. Kadang tidak berpendirian teguh ketika mengerjakan soal lebih terpengaruh sehingga jawabannya berubah.

T: Bagaimana penanaman yang dilakukan Bapak/Ibu dalam membentuk sikap sabar pada diri siswa?

J: Setiap siswa harus bersikap sabar dalam menghadapi semua persoalan dari kehidupan ini terutama sekali dalam menghadapi pelajaran di sekolah khususnya bidang studi SKI, karena sifat sabar adalah kunci keberhasilan. Mengarah pada sifatsifat pada Ulul Azmi dan Rasulullah yang memiliki sifat sabar.

T: Bagaimana penanaman yang dilakukan Bapak/Ibu dalam membentuk sikap optimisme pada diri siswa?

J: $\quad$ Seorang siswa harus optimis dalam menghadapi semua persoalan dan kehidupan khususnya dalam mempelajari/belajar bidang studi 
SKI karena sifat optimisme harus kita terapkan dalam diri kita pribadi. Sifat ini akan menunjang kita dalam belajar berhati-hati dan kita tidak boleh memakai sifat pesimis didalam menghadapi persoalan dalam memecahkan bidang studi SKI.

T: Bagaimana penanaman yang dilakukan Bapak/Ibu dalam menciptakan sikap hidup damai pada diri siswa?

J: Kita setiap siswa harus menanam-kan menciptakan sikap hidup damai terutama sekali dalam suatu kelas di sekolah ini, karena kedamaian itu akan membuat diri kita tentram dalam menghadapi pelajaran di sekolah khususnya dibidang SKI. Contoh penerapannya: kepada adik kelas disayangi, kepada sesama dihargai, kepada kakak kelas dihormati, kepada guru kita harus muliakan.

T: $\quad$ Bagaimana penanaman yang dilakukan Bapak/Ibu dalam membentuk sikap ridha pada diri siswa?

J: Kita sebagai seorang siswa harus ridha menghadapi problema hidup terutama pada pelajaran SKI karena itu sudah merupakan qiradat/kehendak Maha Kuasa. Setiap siswa harus ridha menerima apa adanya yang terjadi pada dirinya sendiri. Sebagai contoh: semua perbuatan kita di ridhoi Allah, orangnya, perbuatan dan kesemuanya.

T: Bagaimana penanaman yang dilakukan Bapak/Ibu dalam membentuk sikap patuh dan taat menjalankan perintah Allah pada diri siswa?

J: $\quad$ Setiap siswa harus bersikap patuh dan taat menjalankan perintah Allah SWT. bila seseorang menjauhi perintah Allah dia akan termasuk orang yang merugi/kecewa. Contoh penera-pannya : setiap siswa dituntut menuntut ilmu terutama yang belajar di sekolah agama kita diperintah untuk menuntut ilmu untuk keselamatan dan kebahagiaan kita baik kehidupan dunia atau akhirat, kemudian perintah shalat. Bila seorang siswa tidak mempunyai sikap patuh dan taat menjalankan perintah Allah dan Rasul-Nya dalam hal menuntut ilmu itu maka ia akan merugikan diri sendiri dan akan merugikan dan mengecewakan orangtuanya.

T: Bagaimana penanaman yang dilakukan Bapak/Ibu dalam membentuk sikap disiplin menjalankan perintah Allah pada diri siswa?

J: Setiap siswa harus mempunyai sikap disiplin yang tinggi dalam menjalankan perintah Allah. Contoh sholat dan puasa, sholat harus dikerjakan tepat waktu dan puasa harus dikerjakan tepat waktu. Penerapannya: seorang siswa harus disiplin menjalankan perintah Allah dalam menuntut ilmu sesuai dengan menuntut ilmu yang diberlakukan contohnya mengikuti proses belajar mengajar di sekolah. Waktu datang ke sekolah, waktu pulang, waktu belajar dan waktu istirahat. Jadi seorang siswa harus disiplin dalam penggunaan waktu. Sesuai dengan surat Al-Ashr: " demi masa. Sesungguhnya manusia itu merugi kecuali orang-rang yang melakukan kebaikan/orang mengamalkan". yang

\section{PEMBAHASAN}

Berdasarkan hasil wawancara yang telah diuraikan secara rinci terhadap data yang diperlukan, maka penanaman nilainilai pendidikan akidah melalui mata pelajaran Sejarah Kebudayaan Islam di antaranya: Pertama, penanaman dalam menjauhkan dari pandangan bahwa 
dirinya yang paling pintar pada diri siswa. Guru menanamkan pada siswa untuk tidak boleh sok pintar, sok tahu, sok mengerti dalam berbagai persoalan karena belum tentu kebenarannya. Kalau perkataannya belum benar maka lebih baik tidak perlu dikatakan. Begitu juga pada siswa, hal itulah yang menyatakan bahwa kita tidak boleh menyatakan pendapat kita itu paling benar, belum tentu apa yang kita katakan itu sesuai dengan ketentuan yang berlaku karena yang benar hanya berpedoman pada AlQur'an dan Hadist. Misalnya ingin mengemukakan pernyataan harus ada landasan yang jelas supaya nantinya tidak ada keraguan didalam hatinya.

Kedua, penanaman dalam menanamkan sikap percaya diri pada diri siswa. Guru menanamkan kepada siswa untuk selalu mengikuti pelajaran dengan baik khususnya dalam bidang studi Sejarah Kebudayaan Islam (SKI) supaya nantinya ketika ujian memiliki rasa percaya diri dalam mengerjakan soal ujian dan mendapat hasil yang maksimal.

$$
\text { Ketiga, penanaman dalam }
$$

menanamkan sikap tahu harga diri. Guru menanamkan kepada siswa bahwa harga diri itu sangat tinggi nilainya. Siswa yang bersekolah di Madrasah Tsanawiyah(MTs) berbeda dengan siswa yang bersekolah umum lainnya karena setiap tingkah laku sehari-harinya akan dilihat dari sudut pandang agamanya. Oleh karena itulah siswa harus menjaga harga diri baik di lingkungan keluarga, di lingkungan sekolah dan lingkungan masyarakat.

Keempat, penanaman dalam menanamkan sikap jujur pada diri siswa, yaitu dengan cara: (a) Guru menanamkan pada siswa untuk bersikap jujur dalam perbuatan dan perkataan baik terhadap diri sendiri, keluarga maupun di lingkungan sekitarnya, karena sikap jujur itu akan mengangkat harkat dan martabat pada diri seseorang; (b) Guru menanamkan pada siswa untuk berlaku jujur dalam belajar seperti mengerjakan soal ujian yang harus jujur pada diri sendiri karena jujur itu dianjurkan dalam ajaran Islam; dan (c) Guru memberikan contoh pada siswa dengan meneladani sifat jujur yang dimiliki Rasulullah SAW.

Kelima, penanaman dalam membentuk sikap adil pada siswa, yaitu dengan cara: (a) Guru menanamkan pada diri siswa untuk bersikap adil terhadap diri sendiri, teman, keluarga maupun lingkungan sekitar; dan (b) Guru menanamkan pada diri siswa untuk bersikap adil dalam perkataan, perbuatan, dan ketetapan dari ketiganya itu harus bersikap adil. Kalau dilihat dari situasi dan kondisi seperti orang tua yang harus berlaku adil kepada anak-anaknya.

Keenam, penanaman dalam menghilangkan sifat murung dalam menghadapi setiap persoalan pada diri siswa. Guru menerapkan pada diri siswa untuk bersikap ceria dan tidak boleh bersifat murung dalam menghadapi setiap persoalan terutama dalam hal belajar karena sifat murung ini dilarang dalam ajaran Islam. Di dalam pembelajaran harus bersikap ceria supaya nantinya mendapatkan hasil yang maksimal.

Ketujuh, penanaman dalam menanamkan sifat putus asa pada diri siswa. Guru menanamkan pada diri siswa agar tidak boleh putus asa dalam menghadapi setiap persoalan terutama dalam menghadapi mata pelajaran Sejarah Kebudayaan Islam (SKI). Kita tidak boleh berputus asa, ketika orang lain bisa melakukannya dan kita juga bisa melakukannya. Didalam pembelajaran Sejarah Kebudayaan Islam (SKI) itu terdapat banyak hafalan dan siswa dituntut untuk berusaha menghafalkannya dan tidak boleh berputus asa.

Kedelapan, penanaman dalam menanamkan sifat kesatria pada diri siswa, yaitu dengan cara: (a) Guru menerapkan pada siswa menanamkan 
sifat kesatriaan pada dirinya sendiri karena siswa adalah sebagai generasi penerus bangsa di masa yang akan datang; dan (b) Guru memberikan contoh dengan meneladani para pejuang tokohtokoh Islam seperti pejuang Islam yang harus diteladani yaitu Salahuddin AlAyubi yang membela agama dan Negara serta dalam hal pendidikan mendirikan beberapa sekolah di Mesir dan Syiria.

Kesembilan, penanaman dalam menanamkan sifat semangat pada diri siswa. Guru menanamkan pada diri siswa untuk memiliki sifat semangat yang tinggi terutama semangat dalam menuntut ilmu, tanpa memiliki semangat yang tinggi dalam pembelajaran Sejarah Kebudayaan Islam (SKI) tidak akan mencapai hasil belajar yang maksimal, karena semangat belajar itu merupakan motivator yang menentukan baik tidaknya hasil yang didapatkan.

Kesepuluh, penanaman dalam menanamkan sifat berani pada diri siswa, yaitu dengan cara: (a) Guru menanamkan pada siswa untuk memiliki sifat berani dalam menghadapi persoalan dan menegakkan kebenaran; dan (b) Guru menanamkan untuk berani dalam mengeluarkan pendapat dalam pembelajaran Sejarah Kebudayaan Islam (SKI), tanpa memiliki keberanian, seorang siswa tidak berani mengeluarkan pendapat terutama dalam mata pelajaran Sejarah Kebudayaan Islam (SKI) dan tidak akan mendapat hasil yang maksimal.

Kesebelas, penanaman dalam menanamkan sifat tidak gentar menghadapi resiko pada diri siswa, yaitu dengan cara: (a) Guru menanamkan pada diri siswa untuk tidak boleh takut dan gentar menghadapi resiko dalam setiap persoalan kehidupan dengan mencontoh perjuangan Rasulullah SAW. dalam perang Badar yang tidak gentar dalam menghadapi resiko meskipun musuh yang dihadapinya sangat banyak demi mempertahankan agama, harga diri umat Islam; dan (b) Guru memberikan contoh dengan meneladani perjuangan Rasulullah ketika menyebarkan Islam ke Ta'if, beliau tidak mendapat sambutan yang baik dan dilempari batu oleh masyarakat sekitar, walaupun begitu beliau tidak gentar menghadapi resiko untuk menyampaikan ajaran Islam pada umat manusia.

Keduabelas, penanaman dalam menanamkan sifat tidak takut mati pada diri siswa. Guru menerapkan pada diri siswa tidak boleh takut untuk menghadapi kematian karena setiap yang bernyawa akan merasakan mati. Kematian itu akan menimpa siapa saja, kapan saja dan dimana saja kita berada. Oleh sebab itu, kita harus siap menghadapi kematian itu sendiri dengan memperbanyak amalan sholeh.

Ketigabelas, Penanaman dalam membentuk sikap berpendirian teguh pada diri siswa. Guru menerapkan pada diri siswa untuk bersikap berpendirian teguh dan tidak ragu-ragu dalam segala tindakan yang dilakukan. Sebagai contoh ketika mengerjakan soal yang lebih terpengaruh dengan orang lain dan tidak berpendirian teguh sehingga jawabannya berubah dan berbeda dengan yang ia buat.

Keempatbelas, penanaman dalam membentuk sikap sabar pada diri siswa, yaitu dengan cara: (a) Guru menanamkan pada diri siswa agar memiliki sikap sabar dalam segala hal kehidupan terutama dalam belajar karena sifat sabar itu kunci dari keberhasilan dan kebanyakanorang yang tidak sabar akan mengalami kegagalan; dan (b) Guru memberikan contoh dengan meneladani para rasul yang ulul azmi yakni rasul-rasul yang memiliki kesabaran yang luar biasa.

Kelimabelas, penanaman dalam membentuk sikap optimisme pada diri siswa. Guru menanamkan pada siswa bersikap optimis dalam menghadapi semua persoalan. Dalam pembelajaran mata pelajaran Sejarah Kebudayaan Islam (SKI) harus bersikap optimis karena sifat 
optimis ini dapat membantu agar lebih berhati-hati dan teliti dalam menyelesaikan masalah serta tidak boleh bersikap pesimis.

Keenambelas, penanaman dalam menciptakan sikap hidup damai pada diri siswa, yaitu dengan cara: (a) Guru mengajarkan siswa untuk menciptakan sikap hidup damai baik di rumah, di sekolah maupun di lingkungan masyarakat yakni yang kecil disayangi, kepada sesama dihargai dan yang tua di hormati; dan (b) Guru mencontohkan sikap hidup damai di sekolah seperti adik kelas disayangi, sesama teman dihargai, kakak kelas dihormati dan dengan guru dimuliakan.

Ketujuhbelas, penanaman dalam membentuk sikap ridha pada diri siswa, yaitu dengan cara: (a) Guru menanamkan pada siswa agar memiliki sikap ridha menghadapi setiap masalah dalam hidup karena itu semua merupakan takdir ataupun kehendak Allah SWT; (b) Guru menanamkanpada diri siswa harus memiliki sikap ridha terhadap pemberian yang diberikan Allah kepada kita; dan (c) Guru mencontohkan bahwa kita ridha terhadap semua perbuatan baik yang dilakukan dan juga diridhai Allah supaya mendapat kebahagiaan di dunia dan di akhirat.

Kedelapanbelas, penanaman dalam membentuk sikap patuh dan taat menjalankan perintah Allah SWT. pada diri siswa, yaitu dengan cara: (a) Guru mengajarkanpada diri siswa untuk bersikap patuh dan taat menjalankan perintah Allah SWT. Apabila seseorang menjauhi perintah Allah maka dia akan termasuk orang yang merugi; dan (b) Guru memberikan contoh yakni siswa yang belajar di sekolah agama diperintahkan untuk menuntut ilmu dan juga diperintahkan untuk sholat dan puasa supaya mendapatkan kebahagiaan dunia dan akhirat. Jika seorang siswa tidak mempunyai sikap patuh dan taat menjalankan perintah Allah dan Rasul-
Nya maka ia akan merugikan diri sendiri dan akan mengecewakan orang tuanya.

Kesembilanbelas, Penanaman dalam membentuk sikap disiplin menjalankan perintah Allah SWT. pada diri siswa, yaitu dengan cara: (a) Guru menanamkan pada diri siswa harus mempunyai sikap disiplin yang tinggi dalam menjalankan perintah Allah. Sebagai contoh sholat harus dilaksanakan tepat waktu begitu pula dengan berpuasa, ketika berbuka harus menyegerakan berbuka; dan (b) Guru memberikan contoh yakni seorang siswa harus disiplin menjalankan perintah Allah dalam hal menuntut ilmu, yaitu mengikuti seluruh proses belajar mengajar disekolah dan menggunakan waktu dengan sebaik-baiknya.

\section{SIMPULAN}

Berdasarkan hasil analisa data yang dilakukan dapat disimpulkan bahwa penanaman nilai-nilai pendidikan akidah melalui mata pelajaran Sejarah Kebudayaan Islam (SKI) Di Mts An-Nur Hangtuah, penanaman yang dilakukan guru Sejarah Kebudayaan Islam (SKI) adalah sebagai berikut: (1) Guru menanamkan sikap percaya diri dan berupaya untuk mempertahankan harga diri; (2) Guru menanamkan untuk berlaku jujur dan adil dengan mencontoh dari kehidupan Rasulullah; (3) Guru menanamkan sikap sabar dan berpendirian teguh dengan meneladani para rasul yang mendapat gelar Ulul Azmi; (4) Guru menanamkan sikap ksatria, semangat dan berani dengan meneladani perjuangan Rasulullah dan para pejuang Islam lainnya; dan (5) Guru menanamkan sikap patuh dan taat menjalankan perintah Allah dengan beriman kepada Allah menjalankan perintahNya seperti sholat, puasa, menuntut ilmu serta menggunakan waktu dengan sebaik-baiknya 


\section{DAFTAR KEPUSTAKAAN}

Ahmadi Abu dan Salimi, Noor. 2008. Dasar-Dasar Pendidikan Agama Islam. Jakarta : PT Bumi Aksara.

Ahmad, Muhammad. 1998. Tauhid Ilmu Kalam. Bandung : CV Pustaka Setia.

Ahmad, Muhammad Abdul Qadir. 2008. Metodologi pengajaran Agama islam. Jakarta : Rineka Cipta.

Alim, Muhammad. 2006. Pendidikan Agama Islam. Bandung : PT Remaja Rosdakarya.

Amin, Samsul Munir. 2015. Sejarah Peradaban Islam. Jakarta: Amzah.

As'ad, Mahrus. 2015. Sejarah Kebudayaan Islam. Bandung : Erlangga.

Dairi, Rizal. 2014. Metodologi Penelitian. Pekanbaru: Uir Press.

Departemen Pendidikan Nasional. 2008. KamusBesar Bahasa Indonesia Pusat Bahasa. Jakarta : PT Gramedia Pustaka Utama.

Ghoni, Muhammad Djunaidi. 1982. Nilai Pendidikan. Surabaya: Usaha Nasional.

Gunawan, Heri. 2012. Pendidikan Karakter, konsep dan implementasi. Bandung: Al-Fabeta.

Hasbullah. 2008. Dasar-Dasar Ilmu Pendidikan. Jakarta : PT Raja Grafindo Persada.

Hayati, N., Noer, M. A., \& Khoirol, W. 2015. Kemampuan Mengelola Interaksi Edukatif Guru Pendidikan Agama Islam. Al-Hikmah: Jurnal Agama dan Ilmu Pengetahuan, 12(2), 117-131.

Hs, M., \& Hasanah, L. 2011. Tauhid: Dasar Pengembangan Kurikulum Pendidikan Islam. Al-Hikmah: Jurnal Agama dan Ilmu Pengetahuan, 8(1), 96-112.

Ihsan, Fuad. 2008. Dasar-Dasar Kependidikan. Jakarta: Rineka Cipta.

Nashir, Haedar. 2013. Pendidikan Karakter Berbasis Agama Dan
Kebudayaan. Yogyakarta: Multi Presindo.

Nata, Abuddin. 1999. Metodologi Studi Islam. Jakarta : PT Raja Grafindo Persada.

Moleong, Lexy J., 2013. Metodologi Penelitian Kualitatif. Bandung : PT Remaja Rosdakarya.

Noer, M. Ali. 2008. Pengantar Ilmu Tauhid. BKS PTAIS RIAU press.

M. Asy'ari. 2011. Konsep Pendidikan Islam. Jakarta : CV. Sejahtera Kita.

Muhaimin. 2005. Pengembangan Kurikulum Pendidikan Islam. Jakarta : Raja Grafindo Persada.

Purnawan, M. Dimas Elsa. 2014. Implementasi Pendidikan Akidah Akhlak Terhadap Dalam Membentuk Perilaku Keagamaan Siswa Kelas V Sekolah Islam Tahfidzul Qur'an (SDTIQ) AL-Irsyad Tahun Pelajaran 2013/2104, Fakultas Agama Islam.

Rosyadi, Khoiron. 2004. Pendidikan Profetik. Yogyakarta: Pustaka Pelajar.

Rosyidah. 2015. Nilai- Nilai Pendidikan Akidah Dalam Novel Zukhruf Kasih Karya Azzura Dayana. Skripsi. Fakultas Agama Islam.

Sagala, Syaiful. 2013. Etika \& Moralitas Pendidikan Peluang dan Tantangan. Jakarta: Kencana Prenada Media Group.

Saputra, Gusti Yosi. 2016. Konsep Pendidikan Aqidah Menurut Pemikiran Prof. Dr. H. Zurkani Jahja, Fakultas Tarbiyah dan Keguruan.

Sudjana, Ohan. 2000. Fenomena Aqidah Islamiyah. Jakarta : Media Dakwah.

Sugiono. 2012. Metode Penelitian Kombinasi (Mixed Methods). Bandung : CV Alfabeta.

Syamsuddin, Ali. 2009. Mengukir Sifat kepribadian Muslim. Yogyakarta : Graha Ilmu. 